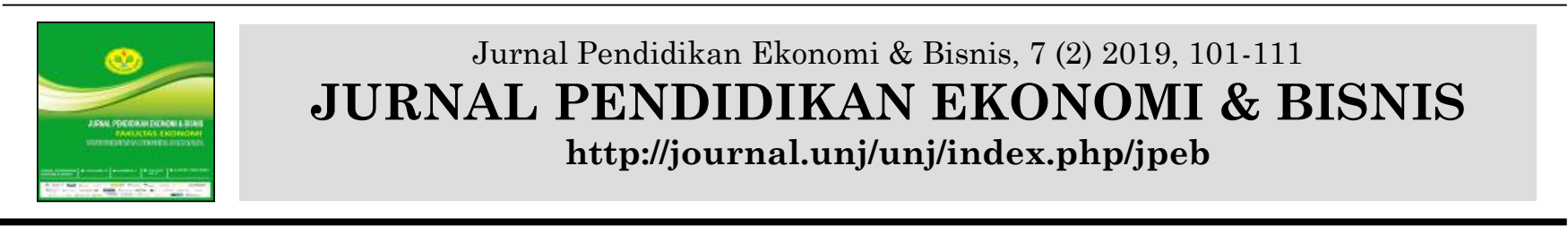

\title{
Social Interaction, Socio-Economic Status, and Basic Economic Knowledge of Students' Economic Behavior
}

\author{
Siti Nurul Qomariyah ${ }^{1}$, Harti $^{2}$, Hariyati ${ }^{3^{*}}$ \\ 1 Universitas Negeri Surabaya, Indonesia \\ 2 Universitas Negeri Surabaya, Indonesia \\ 3 Universitas Negeri Surabaya, Indonesia
}

\section{Article Info}

Article history:

Received: 22 July 2019

Accepted: 20 September 2019

Published: 1 October 2019
Keywords:

Social Interaction; SocioEconomic Status; Basic Knowledge of Economics; Economic Behavior.

\begin{abstract}
This study aims to determine the effect of social interaction, socioeconomic status and basic economic knowledge on the economic behavior of MAN students in the Pati Regency. This research uses a quantitative research approach. This study uses primary data obtained from distributing questionnaires to students. The population in this study amounted to 266 students. A sample of 160 students with a proportional random sampling technique. The data analysis technique used is multiple linear regression analysis. Based on the results of data analysis, there is an influence of social interaction, socioeconomic status and basic economic knowledge on the economic behavior of MAN students in Pati Regency. This is indicated by the results of the $\mathrm{F}$ Test which obtained a significance value of $0.00<0.05$.
\end{abstract}

\begin{abstract}
Abstrak
Penelitian ini bertujuan untuk mengetahui pengaruh interaksi sosial, status sosial ekonomi dan pengetahuan dasar ekonomi terhadap perilaku ekonomi peserta didik MAN di Kabupaten Pati. Penelitian ini menggunakan data primer yang diperoleh dari penyebaran angket pada peserta didik. Populasi dalam penelitian ini berjumlah 266 peserta didik. Sampel sebanyak 160 peserta didik dengan teknik purpotional random sampling. Teknik analisis data yang digunakan adalah analisis regresi linier berganda. Berdasarkan hasil analisis data menunjukkan ada pengaruh interaksi sosial, status sosial ekonomi dan pengetahuan dasar ekonomi terhadap perilaku ekonomi peserta didik MAN di Kabupaten Pati. Hal ini ditunjukkan dengan hasil Uji $F$ yang memperoleh nilai signifikansi sebesar $0.00<0.05$.
\end{abstract}

\section{How to Cite:}

Qomariyah, Siti Nurul., Harti., \& Hariyati. (2019). Social Interaction, Socio-Economic Status, and Basic Economic Knowledge of Students' Economic Behavior. Jurnal Pendidikan Ekonomi \& Bisnis, 7(2), 101-111. https://doi.org/10.21009/JPEB.007.2.1
* Corresponding Author. Siti.17070925408@mhs.unesa.ac.id/ sitinurulqomariyah22@gmail.com (Siti Nurul Qomariyah) 


\section{INTRODUCTION}

The micro-economic perspective, the economic behavior of students can be seen from the behavior of consumers because of the activities of learners tends to be consumptive. In principle, the goal of consumers is to obtain maximum satisfaction from the resources that are limited (Pindyck \& Rubinfeld, 2001). This economic behavior is reflected in the economic actions that humans take every day, influenced by various considerations and choices. Economic action can also be regarded as an activity carried out by considering the sacrifice made with the results obtained. Therefore, this activity is increasingly popular so that it attracts many researchers' attention.

Humans never feel satisfied with meeting their needs. Unlimited needs will be very much at odds with the means of satisfying needs that are limited (Wahana, 2005). Humans always have the desire to meet their needs, so humans are required to use economic principles in their daily activities, therefore humans are said to be homo economicus (Wilkinson, 2008). According to Surjanti (2003) homo economicus, that is, humans in their search for and obtain prosperity always act rationally and consider the sacrifice and benefits of actions taken both for themselves and society/others by norms and values.

There are three common economic activities carried out by humans, namely production, consumption, and distribution. Humans as economic agents will always try to meet their needs with a variety of behaviors, methods, and interactions with other economic actors. Economic behavior is the process of deciding to evaluate the fulfillment of the needs, acquisition, use, and neglect of goods and services in meeting their needs. This economic behavior is reflected in the economic actions that humans take every day, influenced by various considerations and choices. Economic action can also be regarded as an activity carried out by considering the sacrifice made with the results obtained.

Economic actors who carry out consumption activities consist of various sexes and ages, one of them is Madrasah Aliyah Negeri (MAN) students in Pati Regency. In general, in MAN, consumers are in middle age, between the ages of children to adolescents, in middle age, it is considered quite mature in economic behavior, besides they have also gained lessons and economic knowledge from middle school to grade X. Economic behavior in adolescents varies greatly considering the needs and desires that begin to develop. Related to the varied needs and desires, it is necessary to have economic knowledge that will provide an understanding of economic behavior in social life to deal with economic uncertainty.

Witherington (2002) explains that adolescent development is more likely to be on psychological changes that can never be separated from environmental influences. Teenagers judge themselves and assess their environment, especially the social environment. Teenagers are also very easy to follow trends, follow what is "in" between them. This is evidenced by the many teenage behaviors in consumption actions that are not based on rational considerations, namely the application of economic principles and motives in consumption activities, but are more influenced by their environment.

The condition of Pati Regency is different from other districts both territorially, socially and culturally, but developments in various fields, especially technology have eliminated the boundaries between the city and district areas. This can be seen from the rapid development of public facilities in various life accesses such as shopping centers, free wifi, cafes, internet cafes, and so on.

Sunyoto (2014) said that the level of product purchase decided by consumers is strongly influenced by the knowledge held. Knowledge is the process caused by changes in human behavior. Basic knowledge about economics obtained by school students can influence economic behavior patterns in consuming goods or services. In a microeconomic perspective, the economic behavior of students can be seen from consumer behavior because student activities tend to be still consumptive. In principle, the goal of consumers is to obtain maximum satisfaction from the resources that are limited (Pindyck \& Rubinfeld, 2001).

Factors affecting economic behavior are projected to have the socioeconomic-social status of parents, social interaction and learners' knowledge of economics. As we know, parents' socioec- 
onomic status will determine the level of experience in the economic life of students every day. The same thing was stated by Slavin (1994) who found that there was no difference in the activities of parents in guiding children between families with high socioeconomic status and families with low socioeconomic status. Parents with high socioeconomic status have high hopes for the success of their children in school and they often give gifts for children's intellectual development.

Some research by Goldfarb et al. (2012) which states that social interaction influences economic behavior in economic transaction activities. Furthermore Zanella's research (2004) states that social interactions affect economic behavior, individuals who have similar characteristics will choose friends or groups that have similarities with them. So individuals with the same characteristics will tend to sort themselves into the same group.

The results of these studies differ from the results of research conducted by Muna (2018) that peer interaction (social interaction) has no influence on student economic behavior. Begigu also with research conducted by Manski (2000) says that social interaction does not show progress comparable to that achieved in economic behavior. The difference in the results of this study can be caused by various factors, one of which is a different environment, such as family conditions, social and economic status, characteristics of students and teachers, different school or madrasah environments in terms of facilities and infrastructure.

Suprapti (2010) explains that the greatest potential in the market segment exists in adolescents because it has a multidimensional nature, which can be as a primary market segment, market influence, and future markets. Teenagers have very diverse needs so it is said to be the primary market. Teenagers usually have the power to influence the decisions of their parents, so this condition is called an influence market. Meanwhile adolescents are said to be the future market because adolescents are potential market segments for the future with increasing age. The influence of mass media, social interaction, and lifestyle so that students often forget their rationality in economic activities.

In addition to social interaction in the school environment, there are factors that can affect students' economic behavior, namely the socioeconomic status of parents. Socio-economic status will determine the level of student behavior in economic activity. This is in accordance with the opinion of Kustiandi (2011) that the level of social status of parents is an important part because of the different socioeconomic status will distinguish students from one another.

Research conducted by Lindqvist et al. (2018) that socioeconomic status influences economic behavior where low socioeconomic status shows views in the short term and is less rational in spending money compared to owners of high economic status. While Chang's research (2008) which states that parents' socioeconomic status significantly influences consumer behavior, which also positively influences achievement.

From this description it can be concluded that the socioeconomic status influences the economic behavior of students. However, it is different from research conducted by Prasastianta (2016) that the socioeconomic status of parents does not affect the economic behavior of MAN students in Blitar Regency. Furthermore Imansari \& Fitrayati (2016) which states that the socioeconomic status of parents has no significant effect on consumption behavior explains that consumption behavior in the study cannot think of rationality.

MAN Pati Regency is an Aliyah State Madrasah school located in Margorejo District and Tayu District. Students who study at MAN come from different backgrounds, ranging from parents' income, education and work of parents. Departing from the level of education and income of parents who varied, then the large amount of student allowance also varies.

The socioeconomic condition of MAN parents of students in Pati Regency consists of various social statuses, where most of them are people who have income. Based on the work data of parents of students in MAN Pati it is known that most parents work as civil servants, teachers, entrepreneurs, farmers, factory workers, employees, traders, and village officials. Seeing the different working conditions of parents will cause many of the students to get more pocket money so that the economic behavior of students is sometimes less rational in spending their allowance. 
The life of a teenager cannot be separated from the educational process. According to RI Law No. 20 of 2003 concerning the National Education System where education is every conscious and planned effort in creating learning situations and learning activities so that students can actively grow their ability to have religious spiritual strength, moral merit, and abilities needed for themselves, community groups, nation and state. In other words, through education someone will be able to increase their understanding and knowledge.

Economic subjects have an important role in shaping economic behavior, especially in economic decision making. Economics as one of the subjects in Madrasah Aliyah is expected to be able to provide provisions or knowledge to students to have skills in economics, so that students are able to behave rationally in the economy. According to Zamroni (1992) in general, rational means consciously planned human actions through mature thinking in the context of economic action. Humans continually base their actions on achieving economic effectiveness and efficiency. However, empirically, the skills of high school students in using the economy in daily life or in consuming are still very far from expectations (Haryono, 2008).

The knowledge and skills acquired by a person cover all fields of science, economics is no exception. By learning about the institutional aspects of the economy, a person will learn in terms of the limitations faced by someone in making decisions that will affect their allocation of resources (Al-Arif, 2010). MAN in Pati Regency has also provided economic learning from class X as a science in the hope that students will have economic behavior in consuming goods and services.

Research conducted by Koc \& Ceylan (2010) states that knowledge of cognitive skills measured from economic tests and soft skills will have an influence on economic behavior. Furthermore, research by Fiqriyah \& Wahyono (2016) states that the basic understanding of economics influences the rationality of the consumption behavior of class XII students in MAN 1 Malang. The results showed that students when consuming are able to apply the economics they receive in real life and in fact where in real life the basic economic problems are inseparable from every human being. the existence of a good economic understanding and good application, will make children more rational when making consumption decisions.

The results of these studies differ from the results of research conducted by Nokadianti (2013) that the basic knowledge of economic literacy has no influence on the rationality of economic behavior of students. This is because the material taught at school is only limited to information conveyed by economics teachers, students are not actively involved in the learning process. Furthermore, Ruminingsih et al. (2016) research on economic knowledge has no effect on the consumptive behavior of students through consumer attitudes.

Based on the phenomena that occur in Pati about economic behavior actions still do not use logical thoughts and considerations in economic activities. This can be seen from the 20 students who answered questions about economic behavior, the attitude of 17 students in buying goods does not consider the value function of the goods. Then there are 15 students who have not been able to calculate the various possibilities that will occur in economic action taken and $50 \%$ of students also do not take into account the risk in making a decision. This shows that they carry out economic actions without looking at economic principles that have been learned in schools.

Examine this phenomenon and complement earlier findings, this study was designed to determine the economic behavior of learners in Pati regency. who have not used priority scale in meeting their daily needs. The factors used to determine economic behavior are adjusted to the characteristics of the sample who always want to try new things. Therefore in this study the variables used are social interaction, socioeconomic status and basic knowledge of economics and economic behavior. 


\section{METHOD}

The subjects in this study were students of State Madrasah Aliyah (MAN) in Pati Regency. However, not all students can represent the criteria in this study, namely to have a basic knowledge of economic knowledge about economic material, especially economic principles and motives, economic actions, needs and economic law from economic lessons. This material will be obtained when students sit in class X SMA / MA. Therefore class XI is considered to represent the population in this study because it is in a condition of age that is beginning to stabilize (middle adolescents) compared to class X both in terms of peer environment and social attitudes. . In addition, class XI is considered to have sufficient knowledge of the basics of economics. While class XII is not possible in taking data because of teaching and learning activities with a tight schedule for the preparation of the Computer-Based National Examination (UNBK) and the National Standard Madrasah Final Examination (UAMBN).

Techniques for collecting data in this study include Questionnaires, Test. The sampling technique in this study uses Proportional Random Sampling, which is sampling taking into account the consideration of elements or categories in the study population. In random sampling, each class in the population has the opportunity to be sampled. Proportional is used to determine the number of samples in each class. The measurement scale of this research instrument uses a Likert scale with a score criterion of 4 by eliminating neutral choices with the aim that respondents can provide answers that are appropriate to what they experienced and felt. Indicators on the instrument were adapted from the opinions of Sarwono \& Sarlito (2010), Soekanto (2007) and Kahneman (2003).

A study requires valid and reliable data. Before collecting primary data, the instrument should be tested first by conducting the SPSS 20 for the windows validity test with the Pearson product-moment method. the stages were carried out by the author by distributing experimental questionnaires to 30 respondents. The data tested for validity are the results of scores derived from questionnaires that have been filled out by respondents. In this study, to determine the level of validity used SPSS 20 for windows with the Pearson product moment method. Based on the validity test on social interaction variables, invalid instruments were found as many as 2 questions, so they were not used in the research instrument. While the instrument variable socioeconomic status and economic behavior is valid so that the instrument can be used for this study with a larger number of samples. Data analysis techniques in the study used multiple regression analysis with dummy variables. Where the basic knowledge of economics is a dummy variable with a score of 1 for the correct answer and 0 for the wrong answer. Then the hypothesis test is done with the t-test and the significance is 0.05 .

\section{RESULTS AND DISCUSSION}

Respondents in this study were MAN XI IPS students in Pati Regency, with a population of 266 students and a sample of 160 students spread across MAN 1 Pati totaling 55 students, and MAN 2 Pati totaling 105 students. Before using multiple regression analysis, the prerequisite test is a normality test, multicollinearity test, heteroscedasticity test, and linearity test.

From the normality test, the results are obtained that the data is normally distributed. Then from the multicollinearity test, the results showed that all variables do not have multicollinearity problems and the heteroscedasticity test can be said that there is no heteroscedasticity or the homoscedasticity model. A good regression model if no heteroscedasticity is found. Linear test results obtained that all variables are less than 0.05 so the hypothesis stating that the linear model is accepted. The test results are eligible to use multiple regression analysis. Then obtained the multiple linear regression equation as follows: 
Table 1. Table of the results of the regression calculation

\begin{tabular}{llllll}
\hline \multirow{2}{*}{ Model } & \multicolumn{2}{l}{$\begin{array}{l}\text { Unstandardized } \\
\text { Coefficients }\end{array}$} & $\begin{array}{l}\text { Standardized } \\
\text { Coefficients }\end{array}$ & t & \multirow{2}{*}{ Sig. } \\
\cline { 2 - 5 } & $\mathrm{B}$ & $\begin{array}{l}\text { Std. } \\
\text { Error }\end{array}$ & Beta & & \\
\hline (Constants) & 15.614 & 2.986 & & 6.229 & .000 \\
Social Interaction $\left(\mathrm{X}_{1}\right)$ & .366 & .053 & .418 & 6.855 & .000 \\
Socio Economic Status $\left(\mathrm{X}_{2}\right)$ & .462 & .063 & .414 & 2.041 & .000 \\
$\begin{array}{l}\text { B a s i c E c o n o m i c } \\
\text { Knowledge }\left(\mathrm{X}_{3}\right)\end{array}$ & .700 & .343 & .112 & 2.041 & .043 \\
\hline
\end{tabular}

a. Dependent Variable: Economic Behavior lows.

Based on the table above, the multiple linear regression equation in this study is as fol-

$\mathrm{Y}=15,614+0.366 \mathrm{X} 1+0.426 \mathrm{X} 2+0.700 \mathrm{X} 3+\mathrm{ei}$

With the linear regression calculation of the three variables that are positive, this shows that the independent variable has a direct relationship with the dependent variable. A constant of 15,614 ie if all three independent variables (social interaction, socioeconomic status and basic economic knowledge) are considered constant, the economic behavior of students is 15,614 . The regression coefficient X1 of 0.366 states that each increase in social interaction (X1) of 1 unit, the economic behavior of students $(\mathrm{Y})$ will increase by 0.366 , assuming $\mathrm{X} 2$ and $\mathrm{X} 3$ are constant. The regression coefficient X2 of 0.426 states that every increase in socioeconomic status (X2) of 1 unit, the economic behavior of students $(\mathrm{Y})$ will increase by 0.426 , assuming $\mathrm{X} 1$ and $\mathrm{X} 3$ are constant. The regression coefficient X3 of 0.700 states that every increase in basic economic knowledge (X3) of 1 unit, the economic behavior of students (Y) will increase by 0.700 , assuming X1 and X2 are constant.

The determination of the effect of all independent variables on the dependent variable is shown by the magnitude of the regression coefficient $(\mathrm{R})$. Figures obtained will be converted to percent, which means the percentage contribution of the influence of independent variables on the dependent variable. The figures obtained from the table using SPSS 20 are as follows:

Table 2. Results of calculation of multiple linear regression

\begin{tabular}{llll}
\hline Model & $\mathbf{R}$ & Adjusted R Square & Std. Error of the Estimate \\
\hline 1 & $.745^{\mathrm{a}}$ & .546 & 3.28273 \\
\hline Predictors: & $\begin{array}{c}\text { (Constant), Social Interaction, Socio Economic Status and Basic Eco- } \\
\text { nomic Knowledge }\end{array}$ \\
Dependent Variabel: Economic Behavior
\end{tabular}

Based on the table above it can be seen that the value of the correlation coefficient $(\mathrm{R})$ of 0.745. this shows that the relationship of social interaction, socioeconomic status and basic economic knowledge with economic behavior at a level that is quite strong. Hypothesis testing is done using the t-test and the significance level of 0.05. If $t$-Value $=1.975$, the testing hypothesis will be accepted and if the probability value $(\mathrm{P})=0.05$ indicates significance. Hypothesis results have t-value that exceeds the critical point (1.967). Based on the results of testing the first hypothesis it is known that social interaction has a direct positive and significant effect on the eco- 
nomic behavior of students with a $t$ value of 6.855 . The results of this test are supported by research conducted by Goldfarb et al. (2012) and Zanella research (2004). The acceptance of this hypothesis shows that social interactions which include communication, attitudes, group behavior, and social norms influence economic behavior.

The hypothesis test is continued to find out the socioeconomic status of the economic behavior of MAN students in Pati Regency and the results are positive, the research hypothesis is accepted with a t value of 6.809 . The results of this study are supported by previous studies including Lindqvist \& Bjorklund (2018), Chang \& Wei-Lung (2008). Researchers suspect that social status which includes education, employment and income of parents influences economic behavior.

Third hypothesis Testing Results are in line with research by Koc \& Ceylan (2010), Fiqriyah et al. (2016) where the economic knowledge of economic principles, economic motives, economic actions, needs based on their intensity, and knowledge of economic law affect the economic behavior of MAN in Pati Regency using a computer program the statistics are SPSS version 20 for windows.

Table 3. Comparison between $\mathrm{t}$ arithmetic and t table, as well as the Sig-t and Sig- a values of each independent variable

\begin{tabular}{llllll}
\hline \multirow{2}{*}{ Model } & \multicolumn{2}{c}{$\begin{array}{l}\text { Unstandardized } \\
\text { Coefficients }\end{array}$} & $\begin{array}{l}\text { Standardized } \\
\text { Coefficients }\end{array}$ & t & Sig. \\
\cline { 2 - 4 } & $\mathrm{B}$ & $\begin{array}{l}\text { Std. } \\
\text { Error }\end{array}$ & Beta & \\
\cline { 2 - 4 }$($ Constants) & 15.614 & 2.986 & & 6.229 & .000 \\
Social Interaction $\left(\mathrm{X}_{1}\right)$ & .366 & .053 & .418 & 6.855 & .000 \\
$\begin{array}{l}\text { Socio Economic Status }\left(\mathrm{X}_{2}\right) \\
\text { B a s i c E c o n o m i c }\end{array}$ & .462 & .063 & .414 & 2.041 & .000 \\
Knowledge $\left(\mathrm{X}_{3}\right)$ & .700 & .343 & .112 & 2.041 & .043 \\
\hline
\end{tabular}

a. Dependent Variable: Economic Behavior

Based on the table above, then the multiple linear regression equation in this study is Social Interaction $\left(\mathrm{X}_{1}\right)$ has a $t$ value of 6.855 greater than the value of $t$ table $(5 \%)$ at $\mathrm{df}=156$ which is 1.975 , then $\mathrm{H}_{0}$ is rejected and $\mathrm{H}_{\mathrm{a}}$ is accepted which means that social interaction (X1) significantly influence the economic behavior of students $(\mathrm{Y})$ and a significance of 0,000. Socio-Economic Status (X2) has a calculated t value of 6.809 greater than the value of $t$ table (5\%) at $\mathrm{df}=156$ which is 1.975 , then $\mathrm{HO}$ is rejected and $\mathrm{Ha}$ is accepted, which means that socioeconomic status $\left(\mathrm{X}_{2}\right)$ has a significant effect on participants' economic behavior students (Y). This is also evidenced by the sig-t value of the socioeconomic status $\left(\mathrm{X}_{2}\right)$ which is smaller than 0.05 which is equal to 0.00. Basic Knowledge of Economics $\left(\mathrm{X}_{3}\right)$ has a calculated value of 2.041 greater than the value of t table (5\%) at $\mathrm{df}=156$ namely 1.975 , then $\mathrm{HO}$ is rejected and $\mathrm{Ha}$ is accepted, which means that basic knowledge of economics (X3) has a significant effect on participants' economic behavior students $(\mathrm{Y})$. This is also evidenced by the sig-t value of basic economic knowledge $\left(\mathrm{X}_{3}\right)$ which is smaller than 0.05 which is equal to 0.043 .

The findings in this study are consistent with the results of Goldfarb, Mcdevitt, Samila, \& 
nomic status. While research Chang \& Wei-lung (2008) which states that the socioeconomic status of parents significantly influence consumer behavior, which also has a positive effect on achievement. Erni's research (2013) which states that socioeconomic status influences the economic behavior of students. According to Koc \& Ceylan (2010) states that there is a linear relationship between socioeconomic status and consumption behavior, lower economic groups spend part of their income on food products. While groups with high social status tend to pay attention to the food they consume.

However, the results of this study contradict the results of research conducted by Prasastianta (2016) that the socioeconomic status of parents had no effect on the economic behavior of MAN students in Blitar Regency. Furthermore Imansari \& Fitrayati (2016) which states that the socioeconomic status of parents has no significant effect on consumption behavior explains that consumption behavior in the study cannot think of rationality.

The difference in the results of this study can be caused by various factors, one of which is different environmental conditions such as family conditions, social and economic status, different school or madrasa environment, seen from the facilities and infrastructure, the condition of students and teachers. Thus, the findings in this study reveal that socioeconomic status which includes parental education shows the average education of parents of students in MAN Regency Pati graduated from high school / vocational school / MA and only a few students whose parents graduated from bachelor. The parent occupation indicator shows the average work as an entrepreneur. While the average income of parents is in the low category. So that the second hypothesis which reads socioeconomic status significantly influences the economic behavior of MAN students in Pati Regency can be accepted.

Based on the test results, that basic knowledge of the economy has a significant effect on economic behavior. These results mean that each variable of basic economic knowledge will positively influence the economic behavior of students. This is in accordance with the opinion of Caplin in Kustiandi (2011) which states that economic knowledge is needed because every human being is inseparable from economic problems related to how humans can utilize the limitations of the resources they have to meet their various needs.

From the results of the distribution of respondents' answers on the basic knowledge of economic tests showed that from 10 test questions the average was in the high category. the respondent is able to answer correctly but the correct score is mostly found in economic law indicators of demand and economic action. This means that students have the ability to analyze economic law and can provide examples of economic law in their daily activities.

Whereas the economic principles indicator the average score is in the high category, meaning that students have the ability to explain economic principles and determine examples of activities that are in accordance with economic principles. In the indicator of economic motives, the average score is also in the high category, meaning that students can analyze economic motives in the activities carried out by consumers. From the results of the discussion above about basic knowledge of economics on economic behavior of students, supported by research conducted by Koc \& Ceylan (2010) states that knowledge of cognitive skills as measured by tests and economic soft skills will have an influence on economic behavior.

Furthermore, research conducted by Fiqriyah et al. (2016) states that basic understanding of economics influences the rationality of consumption behavior of class XII students in MAN 1 Malang. The results showed that students when consuming are able to apply the economics they receive in real life and in fact where in real life the basic economic problems are inseparable from every human being. the existence of a good economic understanding and good application, will make children more rational when making consumption decisions. They will use and consider their economic principles in taking action to make a choice.

But the results of the above study are different from the results of research conducted by Nokadianti (2013) Basic knowledge of economic learners / economic literacy has no influence on the rationality of economic behavior of students. This is because the material taught at school is only limited to information conveyed by economics teachers, students are not actively involved in 
Silverman's (2012) studies which state that social interaction influences economic behavior in economic transaction activities. This research was conducted at two retail companies, namely in supermarkets and the second on online food transactions that have greater sales thereby increasing producer surpluses. In the indicators of group behavior, most students feel that in making a decision, a deliberation will be conducted first. But there are also students who do not hold deliberations in every decision. Then the indicator of social norms, some students obey school rules and show good behavior and try to say politely to friends and teachers in the school environment.

In the school environment, social interaction that occurs has a close relationship with friendships. Social interaction that occurs in each student will form a group called a group of peers in which consists of peers who are in a certain scope and have characteristics that become the identity of the group. Zanella's research (2004) states that social interactions affect economic behavior, individuals who have similar characteristics will choose friends or groups that have similarities with them. Individuals with the same characteristics will tend to sort themselves into the same group. But the results of the above study are different from the results of research conducted by Muna (2018) that peer interaction (social interaction) has no influence on the economic behavior of students. The difference in the results of this study can be caused by various factors, one of which is a different environment such as family conditions, social and economic status, characteristics of students and teachers, different school or madrasa environment, seen from the facilities and infrastructure.

Thus, the findings in this study reveal that social interactions that include communication show that students engage in exchanging information about daily life with friends. The attitude indicator shows that most students have an attitude of helping to friends and providing solutions to the problems encountered. In the indicators of group behavior, most students feel that in making a decision, a deliberation will be conducted first.

In the indicator of social norms, some students obey school rules and show good behavior and try to say politely to friends and teachers in the school environment. So that the first hypothesis which reads social interaction significantly influences the economic behavior of MAN students in Pati Regency can be accepted. The results of the analysis of research data indicate that socioeconomic status significantly influences the economic behavior of MAN students in Pati Regency. These results mean that any changes in the socioeconomic status variable of parents will have a positive effect on the economic behavior of students.

The socioeconomic status in this study refers to the position of parents in the community based on the ownership of economic resources such as the type of work, the amount of income and the level of education completed. These three things are a measure of the socioeconomic status of parents in the community. Friedman (2004) states that the factors that influence a person's socioeconomic status are education, employment, economic conditions, cultural background and income. Meece (2002) states that students with low socioeconomic status do not understand the full benefits of schools. They do not understand that by getting a good education, they will be able to improve their quality of acceptance in secondary school, good jobs and financial stability. They just think that in the near future they can get a job but in the end they will only become unemployed.

The influence of socioeconomic status in a child's behavior is very large because parents who have high socioeconomic status tend to have a lot of knowledge that can lead their children to positive behavior. The high socioeconomic status of parents ultimately affects students in carrying out economic actions. The socioeconomic status of parents gives the impact of students being more careful in managing finances that have been trained by their parents since childhood. With this independence students are accustomed to making choices in the consumption of goods or services so that students are accustomed to considering the advantages and disadvantages of economic behavior.

The findings of this study are consistent with Lindqvist \& Bjorklund's (2018) research that socioeconomic status influences economic behavior where low socioeconomic status shows views in the short run and is less rational in spending money compared to owners of high eco- 
the learning process. Furthermore, Ruminingsih, Soesilowati, \& Widodo, (2016) research on economic knowledge has no effect on the consumptive behavior of students through consumer attitudes.

The difference in the results of this study can be caused by various factors, one of which is the difference in the process of economic learning that occurred in previous studies with those conducted at this time, different environments such as family conditions, social and economic status, different schools or madrasas in terms of facilities and the infrastructure, the situation of students and teachers. Thus, the findings in this study reveal that basic knowledge of economics which includes knowledge of economic principles, knowledge of economic motives, knowledge of economic actions, knowledge of needs based on its intensity, and knowledge of economic law turns out to affect the economic behavior of students. So that the third hypothesis which reads basic knowledge of economics significantly influences the economic behavior of MAN students in Pati Regency can be accepted.

\section{CONCLUSIONS AND RECOMMENDATIONS}

Based on the discussion of the results of the study, (1) There is a significant influence of social interactions on the economic behavior of MAN students in Pati Regency. This means that social interaction partially has a significant and positive effect on economic behavior. (2) There is a significant influence of socioeconomic status on the economic behavior of MAN students in Pati Regency. This means that socioeconomic status partially has a significant and positive effect on economic behavior. (3) There is a significant influence of basic economic knowledge on the economic behavior of MAN students in Pati Regency. This means that basic knowledge of economics partially has a significant and positive effect on economic behavior. (4) There is a significant influence between social interaction, socioeconomic status and basic economic knowledge together on the economic behavior of MAN students in Pati Regency. The higher social interaction, socioeconomic status and basic knowledge of economics, the higher the economic behavior of students.

MAN students in Pati Regency should carry out social interactions in the school environment always positive things such as carrying out activities carried out together with friends at school, trying to say polite ones, do not speak dirty or offend others, obey the rules at school, do deliberation in making decisions so that it can affect the formation of good character and character in students, especially in economic activities that will have an impact on economic behavior. The improvement of socioeconomic status will be followed by an increase in economic behavior, so parents have an important role in fostering good economic behavior. Parents should always provide guidance to their children in managing economic resources such as pocket money management and parents should be able to provide examples of lifestyle that is not excessive.

MAN students in Pati Regency should always increase basic knowledge of economics which includes knowledge of economic principles, knowledge of economic motives, knowledge of economic actions, knowledge of needs based on its intensity, and knowledge of economic law as a basis for conducting daily economic activities and the formation of good economic behavior. The results obtained may differ if the sample criteria and place of implementation are different. So that further research can be further developed.

\section{REFERENCES}

Chang, W.-L. (2008). Influence of Family Communication Structure and Vanity Trait on Consumption Behaviour: A Case Study of Adolescent Students in Taiwan. Journal of American Academy of Business, Cambridge. Hollywood, 43(2), 170-182.

Fiqriyah, R., \& Wahyono, H. (2016). Pengaruh Pengelolaan Uang Saku, Modernitas, Kecerdasan Emosional dan Pemahaman Dasar Ekonomi terhadap Rasionalitas Perilaku Konsumsi Siswa Kelas X IIS MAN 1 Malang. Jurnal Pendidikan Ekonomi. 
Friedman. (2004). Keperawatan Keluarga. Jakarta: ECG.

Goldfarb, A., Mcdevitt, R. C., Samila, S., \& Silverman, B. (2012). The Effect of Social Interaction on Economic Transactions. Journal of Economic Literature (JEL).

Haryono, A. (2008). Pengaruh System Pembelajaran Dan Status Sosial Ekonomi Terhadap Tingkat Ekonomi Literacy Siswa SMA Dikota Malang. Program Pascasarjana Universitas Negeri Malang.: Disertasi tidak diterbitkan.

Imansari, f. I., \& Fitrayati, D. (2016). Pengaruh Status Sosial Ekonomi Orang Tua terhadap Perilaku Konsumsi Siswa Kelas XI IIs SMAN 17 Surabaya. Jurnal Pendidikan Dan Pembelajaran, 3(9), 1-8.

Kahneman, D. (2003). Maps of Bounded Rationality: Psychology for Behavioral Economics. The American Economic Review, 95(5), 1449-1475.

Koc, B., \& Ceylan, M. (2010). The effects of social-economic status of consumers on purchasing, behaving and attitude to food products. British Food Journal, 114(5), 728-742.

Kustiandi, J. (2011). Faktor-Faktor Yang Yang Berpengaruh Terhadap Perilaku Ekonomi Siswa SMA Negeri Se Kota Malang (Tesis tidak dipublikasikan). Malang: PPS UM.

Lindqvist, A., Björklund, F., \& Universitet, L. (2018). How predictions of economic behavior are affected by the socio-economic status of the target person socio-economic status of the target person. The Journal of Social Psychology, 158(3), 361-378. https:// doi.org/10.1080/00224545.2017.1357527

Manski, C. F. (2000). Economic Analysis of Social Interactions. Journal of Economic Perspectives, 14(3), 115-136.

Muna, L. F. (2018). Pengaruh Status Sosial Ekonomi Orang Tua Dan Pergaulan Teman Sebaya Terhadap Rasionalitas Ekonomi. 344-351.

Nokadianti, S. M. (2013). Pengaruh Status Sosial Ekonomi Orang Tua, Lingkungan dan Pengetahuan Dasar Ekonomi terhadap Rasionalitas Perilaku Konsumsi. Jurnal Pendidikan Humaniora, 1, 55-60. https://doi.org/10.17977/jph.v1i1.3978

Pindyck, R. ., \& Rubinfeld, D. L. (2001). Microeconomic 5th. New Jersey: Prentice Hall.

Prasastianta, D. E. (2016). Pengaruh Status Sosial Ekonomi, Minat pada Pelajaran Ekonomi, dan Literasi Ekonomi terhadap Perilaku Ekonomi Siswa MAN se-Kabupaten Blitar. Tesis. Malang: Universitas Negeri Malang.

Ruminingsih, diyah baiq, Soesilowati, E., \& Widodo, J. (2016). Peran Sikap Konsumen Dalam Memediasi Pengaruh Lingkungan Sosial Dan Pengetahuan Ekonomi Terhadap Perilaku Konsumsi Siswa. Journal of Economic Education, 5(2).

Sarwono, \& Sarlito. (2010). Pengantar Psikologi Umum. Jakarta: PT Grafindo Persada.

Slavin, E. R. (1994). Educational psychology: Theory and Practice. USA: Devision of Paramount Publishing.

Soekanto, S. (2007). Sosiologi Suatu Pengantar. Jakarta: Rajawali Press.

Sunyoto, D. (2014). Perilaku Konsumen. Jakarta: PT Buku Seru.

Suprapti, S. N. W. (2010). Perilaku Konsumen Pemahaman Dasar dan Aplikasinya dalam Strategi pemasaran. Denpasar: Udayana University Press.

Surjanti, J. (2003). Pengaruh Persepsi Kegiatan Pembelajaran Ekonomi Terhadap Pembentukan Sikap Homo Economicus Bermoral pada Mata Pelajaran Ekonomi di SMAN 2 Surabaya. 85 -91 .

Wahana. (2005). Pengantar Mikro Ekonomi Jilid 1. Terjemahan Cetakan Pertama. Jakarta: Binarupa Aksara.

Wilkinson, N. (2008). An Introduction to behavioural economic. New York: Palgrave Macmilan.

Witherington, C. (2002). Psikologi Pendidikan Terjemahan M Ngalim Purwanto. Jakarta: Remaja Rindu Jaya.

Zamroni. (1992). Pengantar Pengembangan teori sosial. Yogyakarta: PT Tiara Wacana.

Zanella, G. (2004). Social Interactions and Economic Behavior. 1-49. 